\title{
A SUMMARY OF THE VARIATIONS IN RELATIVE ABUNDANCE OF THE LANTHANIDES AND YTTRIUM IN ALLANITES AND EPIDOTES
}

\author{
MICHAEL FLEISCHER
}

\begin{abstract}
FLEISCHER, MICHAEL, 1985: A summary of the variations in relative abundance of the lanthanides and yttrium in allanites and epidotes. Bull. Geol. Soc. Finland 57, Part 1-2, 151-155.

Recalculation of 506 analyses of allanites and 53 analyses of epidotes has confirmed that these minerals preferentially concentrate the light lanthanides, but that the relative concentrations vary considerably with variation of the host rocks, with increasing concentrations of the light lanthanides in allanite from granitic pegmatites to granites to granodiorites to carbonatites to alkalic rocks to alkalic pegmatites. The status of the series allanite - allanite - (Y) and the possibility of the existence of allanite - (La) are discussed briefly.
\end{abstract}

Key words: allanite, epidote, chemical composition, REE.

Michael Fleischer: Department of Mineral Sciences, Smithsonian Institution, Washington, D.C., 20560 U.S.A.

\section{Introduction}

This paper is dedicated to the memory of my friend Thure G. Sahama. Appropriately, the subject is an aspect of mineralogy and geochemistry in which he was a pioneering investigator (Sahama and Vähätalo 1939, 1941; Sahama 1945), as he was in so many others.

Allanite and epidote were long ago recognized as concentrators of the light lanthanides (»Cerich») (Goldschmidt and Thomassen 1924; Semenov 1963; Fleischer 1965). The variation in relative abundances of the lanthanides in allanite was recognized by Murata et al. (1957) and its relation to the calcium content of host rocks was proved by Lee and Bastron (1967). Many new analyses have been published in recent years, especially in the U.S.S.R., and it seemed worthwhile to summarize the available data on the distribution of the lanthanides and yttrium in these minerals* and to compare these data with those for other minerals.

\section{Chemistry of allanite}

Table 1 gives averages and Table 2 gives ranges of composition for allanites from 6 types of rocks; available data are insufficient for meaningful averages for samples from other types of rocks. Table 3 gives averages and ranges of composition for epidotes from 3 types

\footnotetext{
* Analyses of 506 allanites and 53 epidotes, recalculated to atomic percentages, will be listed in a U.S. Geol. Survey Open-File Report, to be published.
} 


\section{Michael Fleischer}

Table 1. Average content of lanthanides and yttrium in allanites, atomic per cent.

\begin{tabular}{|c|c|c|c|c|c|c|}
\hline & 1. & 2. & 3. & 4. & 5. & 6. \\
\hline $\mathrm{La}$ & 22.2 & 25.3 & 29.3 & 32.4 & 33.3 & 34.9 \\
\hline $\mathrm{Ce}$ & 43.2 & 48.1 & 48.4 & 49.5 & 49.6 & 50.8 \\
\hline $\mathrm{Pr}$ & 5.7 & 5.0 & 4.3 & 4.1 & 4.3 & 3.8 \\
\hline $\mathrm{Nd}$ & 15.9 & 15.4 & 13.5 & 12.1 & 11.1 & 9.1 \\
\hline $\mathrm{Sm}$ & 4.1 & 2.4 & 1.8 & 0.9 & 0.7 & 0.6 \\
\hline $\mathrm{Eu}$ & 0.2 & 0.1 & - & 0.1 & - & - \\
\hline Gd & 3.8 & 1.3 & 2.0 & 0.3 & 0.2 & 0.3 \\
\hline $\mathrm{Tb}$ & 0.4 & 0.1 & 0.1 & - & - & - \\
\hline Dy & 2.1 & 1.2 & 0.3 & 0.3 & 0.4 & 0.2 \\
\hline Ho & 0.3 & 0.3 & - & - & - & 0.1 \\
\hline Er & 0.9 & 0.3 & 0.3 & 0.1 & 0.1 & 0.1 \\
\hline $\mathrm{Tm}$ & 0.1 & - & - & - & - & - \\
\hline $\mathrm{Yb}$ & 0.9 & 0.4 & 0.1 & 0.2 & 0.2 & 0.1 \\
\hline $\mathrm{Lu}$ & 0.2 & 0.1 & - & - & - & - \\
\hline $\mathrm{Y} /(\mathrm{Y}+\mathrm{Ln}) \times 100$ & $(9.6)$ & $(6.8)$ & $(2.2)$ & $(-)$ & $(0.3)$ & $(1.1)$ \\
\hline no. of analyses & 114 & 139 & 29 & 11 & 13 & 24 \\
\hline$\Sigma=\mathrm{La}+\mathrm{Ce}+\mathrm{Pr}$ & 71.1 & 78.4 & 81.9 & 86.0 & 87.2 & 89.5 \\
\hline $\mathrm{La}-\mathrm{Nd}$ & 87.0 & 93.8 & 95.4 & 98.1 & 98.3 & 98.6 \\
\hline Sm-Ho & 10.9 & 5.4 & 4.5 & 1.6 & 1.4 & 1.2 \\
\hline Er-Lu & 2.1 & 0.8 & 0.1 & 0.3 & 0.3 & 0.2 \\
\hline $\mathrm{RE}_{2} \mathrm{O}_{3}, \%$ & 19.5 & 22.6 & 20.1 & 23.9 & 20.6 & 22.2 \\
\hline $\mathrm{La} / \mathrm{Nd}$ & 1.39 & 1.59 & 2.18 & 2.68 & 3.00 & 3.82 \\
\hline
\end{tabular}

1. Average of 114 from granite pegmatites; 2. Average of 139 from granites; 3. Average of 29 from granodiorites; 4 . Average of 11 from carbonatites; 5. Average of 13 from alkalic rocks; 6. Average of 24 from alkalic pegmatites.

Table 2. Ranges of composition of allanites, atomic per cent. Numbers same as in Table 1.

\begin{tabular}{|c|c|c|c|c|c|c|c|c|c|c|c|c|}
\hline & & 1 & & 2 & & 3 & & 4 & & 5 & & 6 \\
\hline $\mathrm{La}$ & 1.5 & -43.2 & 3.5 & -33.9 & 9.1 & -45.2 & 18.3 & -39.3 & 22.3 & -41.3 & 22.2 & -39.4 \\
\hline $\mathrm{Ce}$ & 2.4 & -59.6 & 3.5 & -69.2 & 33.6 & -56.5 & 41.7 & -54.2 & 45.9 & -53.9 & 35.9 & -53.5 \\
\hline $\operatorname{Pr}$ & 0.2 & -14.8 & 0 & -12.9 & 0 & -10.1 & 3.2 & -5.4 & 2.6 & -8.4 & 2.0 & -6.4 \\
\hline $\mathrm{Nd}$ & 0.4 & -35.2 & 9.2 & -27.1 & 4.2 & -31.4 & 8.3 & -18.7 & 4.7 & -20.9 & 5.8 & -21.2 \\
\hline $\mathrm{Sm}$ & 1.2 & -25.6 & 0 & -25.8 & 0 & -8.1 & 0 & -3.1 & 0 & -2.6 & 0 & -2.5 \\
\hline $\mathrm{Eu}$ & 0 & -2.6 & 0 & -4.7 & 0 & $-\quad 0.2$ & 0 & -0.6 & 0 & $-\quad 0.1$ & 0 & -1.5 \\
\hline Gd & 0 & -29.0 & 0 & -12.8 & 0 & $-\quad 5.5$ & 0 & -1.7 & 0 & $-\quad 0.9$ & 0 & -1.2 \\
\hline $\mathrm{Tb}$ & 0 & -4.2 & 0 & $-\quad 1.9$ & 0 & -0.5 & 0 & -0.3 & 0 & $-\quad 0.1$ & 0 & -0.2 \\
\hline Dy & 0 & -28.3 & 0 & -18.4 & 0 & $-\quad 2.0$ & 0 & -2.2 & 0 & -1.5 & 0 & -1.2 \\
\hline Ho & 0 & -8.5 & 0 & -18.1 & 0 & $-\quad 0.3$ & 0 & $-\quad 0.2$ & 0 & $-\quad 0.3$ & 0 & -1.9 \\
\hline Er & 0 & -22.0 & 0 & -12.1 & 0 & $-\quad 1.1$ & 0 & -1.5 & 0 & -0.6 & 0 & -1.4 \\
\hline $\mathrm{Tm}$ & 0 & -3.5 & 0 & -12.4 & 0 & $-\quad 0.1$ & & - & 0 & -0.1 & & - \\
\hline $\mathrm{Yb}$ & 0 & -25.1 & 0 & -28.0 & 0 & -1.0 & 0 & -1.3 & 0 & -1.3 & 0 & -1.6 \\
\hline $\mathrm{Lu}$ & 0 & -5.1 & 0 & -17.2 & 0 & -0.1 & & - & 0 & -0.2 & 0 & -0.1 \\
\hline $\mathrm{Y} /(\mathrm{Y}+\mathrm{Ln}) \times 100$ & 0.2 & -64.1 & $(0.1$ & $-33.6)$ & $(0.1$ & $-5.9)$ & & - & $(0$ & $-\quad 0.4)$ & $(0$ & $-5.7)$ \\
\hline$=\mathrm{La}+\mathrm{Ce}+\mathrm{Pr}$ & 4.1 & -93.1 & 7.0 & -100.0 & 65.4 & -94.0 & 72.0 & -95.8 & 76.3 & -99.8 & 74.8 & -93.2 \\
\hline La-Nd & 4.5 & -99.7 & 7.0 & -100.0 & 86.2 & -100.0 & 89.0 & -100.0 & 95.9 & -100.0 & 94.9 & -99.9 \\
\hline Sm-Ho & 0 & -72.1 & 0 & -41.5 & 0 & -13.5 & 0 & -7.8 & 0 & $-\quad 3.9$ & 0.1 & -4.6 \\
\hline $\mathrm{Er}-\mathrm{Lu}$ & 0 & -55.7 & 0 & -51.5 & 0 & -2.1 & 0 & -3.2 & 0 & -2.2 & 0 & -3.0 \\
\hline $\mathrm{RE}_{2} \mathrm{O}_{3}$ & 10.2 & -38.3 & 10.0 & -38.3 & 11.6 & -31.1 & 18.0 & -26.3 & 19.1 & -22.2 & 19.3 & -27.5 \\
\hline $\mathrm{La} / \mathrm{Nd}$ & 0.30 & $0-6.81$ & 0.50 & $0-8.90$ & 0.46 & -6.67 & 1.08 & $8-4.17$ & 1.19 & $9-8.09$ & 1.53 & $3-6.60$ \\
\hline
\end{tabular}


A summary of the variations in relative abundance of the lanthanides and yttrium in allanites and epidotes 153

Table 3. Average content of lanthanides and yttrium in epidotes, atomic per cent, and ranges of content.

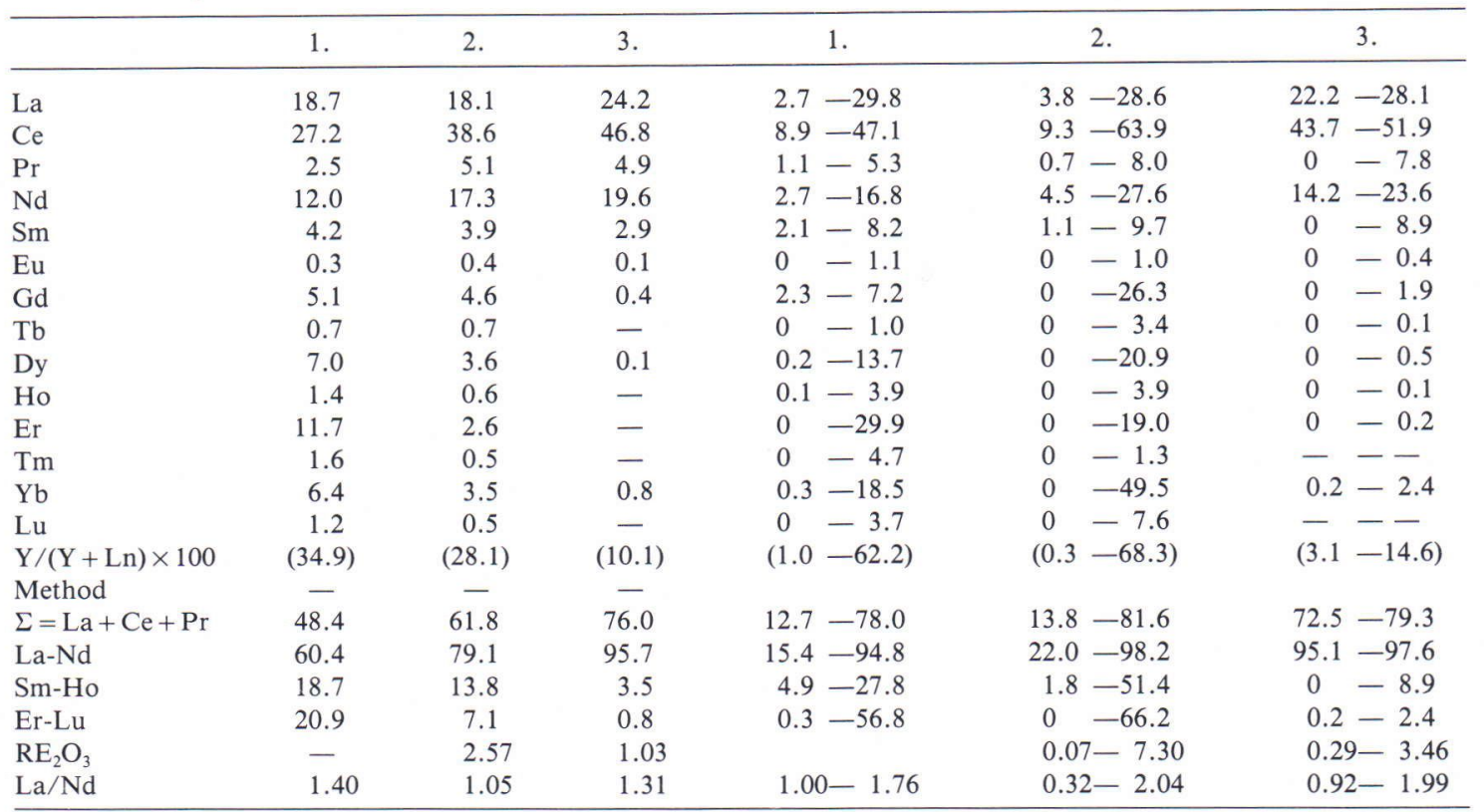

1. Average of 3 from granite pegmatites; 2. Average of 22 from granites; 3 . Average of 5 from gneisses

Table 4. Previous estimates of average composition of allanites (nos. 1-6) and of epidotes (nos. 7-9), atomic per cent.

\begin{tabular}{|c|c|c|c|c|c|c|c|c|c|}
\hline & 1. & 2. & 3. & 4. & 5. & 6. & 7. & 8. & 9. \\
\hline $\mathrm{La}$ & 25.1 & 26.4 & 29.2 & 22.4 & 2.9 & 27.5 & 15.3 & 15.9 & 16.2 \\
\hline $\mathrm{Ce}$ & 49.3 & 50.4 & 61.4 & 60.0 & 5.4 & 46.4 & 35.3 & 36.6 & 38.4 \\
\hline $\mathrm{Pr}$ & 4.6 & 5.2 & - & - & 0.9 & 4.8 & 4.5 & 5.3 & 5.5 \\
\hline $\mathrm{Nd}$ & 16.3 & 15.3 & 9.4 & 17.6 & 3.9 & 15.1 & 12.7 & 16.9 & 16.7 \\
\hline $\mathrm{Sm}$ & 1.9 & 1.3 & - & - & 7.9 & 2.3 & 6.0 & 4.3 & 4.7 \\
\hline $\mathrm{Eu}$ & 0.1 & 0.1 & - & - & 0.9 & - & 0.3 & 0.5 & 0.5 \\
\hline $\mathrm{Gd}$ & 1.4 & 0.4 & - & - & 27.3 & 1.7 & 5.7 & 4.8 & 5.4 \\
\hline $\mathrm{Tb}$ & 0.1 & 0.1 & - & - & 4.0 & 0.1 & 2.5 & 0.8 & 0.9 \\
\hline Dy & 0.5 & 0.5 & - & - & 24.5 & 1.0 & 6.1 & 3.3 & 4.6 \\
\hline Ho & - & - & - & - & 3.8 & 0.2 & 0.6 & 0.8 & 1.0 \\
\hline $\mathrm{Er}$ & 0.3 & 0.1 & - & - & 8.0 & 0.4 & 3.8 & 2.6 & 3.2 \\
\hline $\mathrm{Tm}$ & 0.1 & - & - & - & 1.1 & - & 1.3 & 0.3 & 0.3 \\
\hline $\mathrm{Yb}$ & 0.3 & 0.2 & - & - & 7.8 & 0.5 & 4.9 & 6.9 & 2.4 \\
\hline $\mathrm{Lu}$ & - & - & - & - & 1.6 & - & 1.0 & 1.0 & 0.2 \\
\hline $\mathrm{Y} /(\mathrm{Y}+\mathrm{Ln}) \times 100$ & - & - & (1.6) & - & - & - & - & - & - \\
\hline Method & - & - & $\mathrm{XF}$ & $\mathrm{XF}$ & - & - & - & - & - \\
\hline$\Sigma=\mathrm{La}+\mathrm{Ce}+\mathrm{Pr}$ & 79.0 & 82.0 & 90.6 & 82.4 & 9.2 & 78.7 & 55.1 & 57.8 & 60.1 \\
\hline La-Nd & 95.3 & 97.3 & 100.0 & 100.0 & 13.1 & 93.8 & 67.8 & 74.7 & 76.8 \\
\hline Sm-Ho & 4.0 & 2.4 & - & - & 68.4 & 5.3 & 21.2 & 14.5 & 17.1 \\
\hline Er-Lu & 0.7 & 0.3 & - & - & 18.5 & 0.9 & 11.0 & 10.8 & 6.1 \\
\hline $\mathrm{RE}_{2} \mathrm{O}_{3}$ & - & - & - & - & - & - & - & - & - \\
\hline $\mathrm{La} / \mathrm{Nd}$ & 1.54 & 1.73 & 3.11 & 1.27 & 0.74 & 1.82 & 1.21 & 0.98 & 0.97 \\
\hline
\end{tabular}

(1-2). Lyakhovich and Balanova (1971); (1) av. of 14 from metasomatic granites, (2) av. of 22 from palingenic intrusive granites; (3-4) Frondel (1964), (3) av. of 4 from granites; (4) av. of 24 from granitic pegmatites; (5-6) Mineev (1968), (5) av. of 10 »yttro-orthites, presumably from granitic pegmatites; (6) av. of 58, provenance not stated, (7-8) Lyakhovich and Balanova (1971), (7) av. of 2 from metasomatic granites, (8) av. of 15 from palingenic granites; (9) Mineev (1968), av. of 10 , provenance not stated.

$\mathrm{XF}=\mathrm{x}$-ray fluorescence 
of rocks; only the average of granites is based on a sufficent number of analyses to be reasonably well established.

The data for allanite show that its content of the light lanthanides increases progressively from granitic pegmatite to granite to granodiorite to carbonatite to alkalic rocks to alkalic pegmatites, in accord with previous data for monazite, apatite, and titanite (Fleischer and Altschuler 1969; Fleischer 1965, 1978). The averages for allanite and monazite are similar; those for epidote indicate less concentration of the light lanthanides.

The ranges of concentration for each type of rock, as shown in Tables 2 and 3, are much wider for allanite and epidote than for monazite, apatite, and titanite, making for greater uncertainty in the correlation of composition with paragenesis for allanite, and therefore lessening its value as a diagnostic mineral.

Table 4 quotes averages previously published for the distribution of lanthanides and yttrium in allanite and epidote. In the 55 analyses published by Frondel (1964), only La, Ce, Nd, and $\mathrm{Y}$ were determined, so that her values for $\Sigma$ $(=\mathrm{La}+\mathrm{Ce}+\mathrm{Pr})$ are probably too high; these analyses were not included in the calculations summarized in Table 1.

It would be interesting to compare the data for allanite and epidote with those for the other members of the epidote group: zoisite, clinozoisite, piemontite, and hancockite, especially the latter two; no analyses have been published.

The literature contains many complete chemical analyses of samples, mostly from granitic pegmatites, that correspond closely to normal allanite in composition, except that yttrium predominates over any of the lanthanides. It has generally been assumed that there is a continuous series from allanite (Fallanite-(Ce)) to allanite-(Y) (called yttro-orthite in many papers). The distribution of the lanthanides has been determined for 9 such samples included in Table 1 and for two others published by Frondel (1964).
A plot of $\Sigma$ agains $100 \mathrm{Y} /(\mathrm{Y}+\mathrm{Ln})$ does show a more or less continuous variation, but there is considerable scatter of points. The two samples analyzed by Frondel (1964) calculate to $\Sigma=74.5$ and 73.3, with $100 \mathrm{Y} /(\mathrm{Y}+\mathrm{Ln})=58.5$ and 59.4 , which are far removed from all other samples in the plot. Most analyses with high Y show appreciable amounts of the intermediate lanthanides, especially Gd, Dy, and Er, which Frondel did not determine, so that her values of $\Sigma$ may be too high. She states that these two samples, recrystallized after heating for three days, gave $\mathrm{x}$ ray patterns somewhat different from that of allanite, and might represent a new species.

Further work, especially x-ray study of hydrothermally synthesized La-, Ce-, and Y-rich allanites, is highly desirable to settle this problem.

\section{Does Allanite - (La) exist?}

Among the 506 analyses of allanite considered in this paper, there are nine in which the atomic per cent of $\mathrm{La}$ exceeds that of $\mathrm{Ce}$ and one analysis in which they are equal. These are listed in Table 5 . It will be noted that nearly all the samples are from granitic rocks or gneisses. Comparison with Table 1 shows that in most allanites from such rocks, the ratio $\mathrm{La} / \mathrm{Ce}$ is rather low. One is tempted to ascribe these re-

Table 5. Analyses of Allanite with $\mathrm{La}=$ or $>\mathrm{Ce}$ (At. Per Cent).

\begin{tabular}{|c|c|c|c|c|}
\hline & $\mathrm{La}$ & $\mathrm{Ce}$ & $\begin{array}{c}\text { Ratio } \\
\mathrm{La} / \mathrm{Ce}\end{array}$ & Reference \\
\hline 1. & 3.5 & 3.5 & 1.00 & Putalova (1978), granite \\
\hline 2. & 23.8 & 23.6 & 1.01 & $» \quad »$ \\
\hline 3. & 27.9 & 27.7 & 1.01 & $\gg$ \\
\hline 4. & 38.5 & 38.2 & 1.01 & granodiorite \\
\hline 5. & 42.2 & 41.9 & 1.01 & granite \\
\hline 6. & 45.6 & 45.2 & 1.01 & syenite \\
\hline 7. & 46.2 & 41.0 & 1.13 & Hugo (1961) granulite gneiss \\
\hline 8. & 50.5 & 35.1 & 1.44 & $»$ \\
\hline 9. & 45.2 & 42.7 & 1.06 & \multirow{2}{*}{$\begin{array}{l}\text { Ghent (1972) quartz monzonite } \\
\text { Jesus Ojeda and Mendoza A. } \\
\text { (1981), type of rock not given }\end{array}$} \\
\hline 10. & 45.1 & 44.1 & 1.02 & \\
\hline
\end{tabular}


sults to analytical error or to error in transcription of the data, but such an interpretation is certainly unproved. For example, in the most obvious case in Table 5, Putalova (1978) gives six analyses of allanite, five from granites, one from syenite, each of them with an abnormal ratio $\mathrm{La} / \mathrm{Ce}$. On the other hand, the same paper gives 10 analyses of titanite from granitic rocks

\section{References}

Fleischer, Michael, 1965. Some aspects of the geochemistry of yttrium and the lanthanides. Geochim. et Cosmochim. Acta 29, 775-772.

Fleischer, Michael, 1978. Relation of the relative concentration of lanthanides in titanite to type of host rocks. Am. Mineral. 63, 869-873.

Fleischer, Michael \& Altschuler, Z. S., 1969. Relationship of the rare-earth composition of minerals to geological environment. Geochim. et Cosmochim. Acta 33, 725732.

Frondel, J. W., 1964. Variation of some rare earths in allanite. Am. Mineral. 49, 1159-1177.

Goldschmidt, V. M.\& Thomassen, L., 1924. Geochemische Veteilungsgesetze der Elemente. III Röntgenspektrographische Untersuchungen über die Verteilung der seltenen Erdmetalle in Mineralen. Videnskaps Skrifter I, Mat. - Nat. Klasse no. 5, 1-58.

Ghent, E. D., 1972. Electron microprobe study of allanite from the Mt. Falconer quartz monzonite pluton, lower Taylor Valley, South Victoria Land, Antarctica. Can. Mineral. 11, 526-530.

Hugo, P. J., 1961. The allanite deposits of Vrede, Gordonia district, Cape Province. Rep. S. Africa Dep. Mines, Geol. Surv. Bull. 37, 1-65.

Jesus Ojeda, Maria \& Mendoza A., Atilio, 1981. Distribution of rare earths in zircons, fluorites, apatites, garnets, and allanites from Peru. Bol. Soc. Quim. Peru 1981, with ratio $\mathrm{La} / \mathrm{Ce} 0.33$ to 0.49 , average 0.39 , in reasonable agreement with the average for 83 titanites from granitic rocks, $\mathrm{La} / \mathrm{Ce}=0.29$.

Considering that only one of these ten analyses shows a ratio $\mathrm{La} / \mathrm{Ce}$ much greater than one, the existence of allanite-(La) remains to be proved. It might reasonably be expected to occur in carbonatites or alkalic rocks or alkalic pegmatites.

179-192 (in Spanish).

Lee, D. E. \& Bastron, Harry, 1967. Fractionation of rareearth elements in allanite and monazite as related to geology of the Mt. Wheeler mine area, Nevada. Geochim. et Cosmochim. Acta 31, 339-356.

Lyakhovich, V. V. \& Balanova, T. T., 1971. Average contents and composition of rare-earth elements in accessory minerals of granitic rocks. Geokhimiya 1971, 131143 (in Russian).

Murata, K. J.; Rose, H. J., Jr.; Carron, M. K. \& Glass, J. $J ., 1951$. Systematic variation of rare-earths in ceriumearth minerals. Geochim. et Cosmochim. Acta 11, $141-161$.

Putalova, R. V., 1978. Accessory minerals of granitic intrusives of the Chingiz meganticlinorium. Izdat. »Nauka», Kazakh S.S.R., Alma-Ata 1978, 150 pp. (in Russian).

Sahama, T. G., 1945. Spurenelemente der Gesteine in südlichen Finnisch-Lappland. Comm. geol. Finlande, Bull. 135, 1-86.

Sahama, T. G. \& Vähätalo, Veikko, 1939. The rare-earth content of wiikite. Comm. Geol. Finlande, Bull. 125, 97-109.

Sahama, T. G. \& Vähätalo, Veikko, 1941. X-ray spectrographic study of the rare earths in some Finnish eruptive rocks and minerals. Comm. Geol. Finlande, Bull. 126, $50-83$.

Semenov, E. I., 1963. Mineralogy of the rare earths. Izdat. Akad. Nauk S.S.S.R., Moscow, 410 p. (in Russian) 